Article

\title{
Novel Selective and Potent EGFR Inhibitor that Overcomes T790M-Mediated Resistance in Non-Small Cell Lung Cancer
}

\author{
Yanxia Li ${ }^{1,2}$, Zhendong Song ${ }^{3}$, Yue Jin ${ }^{3}$, Zeyao Tang ${ }^{3}$, Jian Kang ${ }^{1, *}$ and Xiaodong Ma ${ }^{3, *}$ \\ 1 Institute of Respiratory Diseases, The First Affiliated Hospital of China Medical University, \\ Shenyang 110001, Liaoning Province, China; liyanxia001@163.com \\ 2 Department of Respiratory Medicine, The First Affiliated Hospital of Dalian Medical University, \\ Dalian 116011, Liaoning Province, China \\ 3 College of Pharmacy, Dalian Medical University, Dalian 116044, Liaoning Province, China; \\ Songzhen@163.com (Z.S.); rutin@sina.com (Y.J.); tangzeyao@aliyun.com (Z.T.) \\ * Correspondence: Kangjian58@163.com (J.K.); xiaodong.ma@139.com (X.M.); \\ Tel./Fax: +86-24-8328-3195 (J.K.); +86-411-8611-0419 (X.M.)
}

Academic Editor: James W. Leahy

Received: 30 September 2016; Accepted: 29 October 2016; Published: 2 November 2016

\begin{abstract}
Treating patients suffering from EGFR mutant non-small cell lung cancer (NSCLC) with first-generation EGFR tyrosine kinase inhibitors (EGFR TKI) provides excellent response rates. However, approximately $60 \%$ of all patients ultimately develop drug resistance due to a second T790M EGFR TKI mutation. In this study, we report the novel molecule $\mathrm{N}$-(3-((5-chloro-2-(4-((1-morpholino)methyl)phenylamino)-4-pyrimidinyl)amino)phenyl)acrylamide (DY3002) to preferentially inhibit the EGFR T790M mutant $\left(\mathrm{EGFR}^{\mathrm{T} 790 \mathrm{M}}\right)\left(\mathrm{IC}_{50}=0.71 \mathrm{nM}\right)$ over wild-type EGFR $\left(\mathrm{IC}_{50}=448.7 \mathrm{nM}\right)$ in kinase assays. Compared to rociletinib $(\mathrm{SI}=21.4)$ and osimertinib $(\mathrm{SI}=40.9)$, it significantly increased selectivity $(\mathrm{SI}=632.0)$ against $\mathrm{EGFR}^{\mathrm{T} 790 \mathrm{M}}$ over wild-type EGFR. Furthermore, in cell-based tests, DY3002, with an $\mathrm{IC}_{50}$ value of $0.037 \mu \mathrm{M}$, exhibited enhanced inhibitory potency against H1975 cells. Moreover, AO/EB and DAPI staining assays as well as flow cytometer analyses indicated that DY3002 possesses superior biological properties compared to alternatives. In addition, a rat oral glucose tolerance test revealed that treatment with high drug doses $(50 \mathrm{mg} / \mathrm{kg}$ ) of DY3002 did not result in hyperglycemia, suggesting a reduction of side effects in NSCLC patients will be achievable relative to established EGFR inhibitors. In summary, our findings indicate DY3002 as a promising preclinical candidate for effective treatment of patients with EGFR ${ }^{\mathrm{T} 790 \mathrm{M}}$-mutated NSCLC.
\end{abstract}

Keywords: NSCLC; EGFR T790M; resistance; pyrimidine; inhibitor

\section{Introduction}

Non-small cell lung cancer (NSCLC) accounts for approximately $85 \%$ of all lung cancers [1]. Genetic aberrations within the tyrosine kinase domain of the epidermal growth factor receptor (EGFR) have been identified as key drivers of NSCLC progression [2]. Inhibition of the EGFR kinase domain and resulting oncogenic cell signaling disruption via small molecule inhibitors, such as gefitinib (1) and erlotinib (2) (Figure 1) has been shown to be particularly beneficial for patients carrying the so-called "sensitizing mutations", such as L858R or the exon-19 deletion [3-5]. Although such EGFR inhibitor drugs exhibit high response rates, clinical experiments demonstrated that approximately $60 \%$ of patients would eventually suffer from drug resistance after a treatment period, due to a conversion of the "gatekeeper" threonine 790 to methionine (T790M) [6-8]. 
Recently, irreversible EGFR inhibitors have been developed that contain a Michael acceptor functional group and that circumvent the T790M mutation-related resistance. These inhibitors form a covalent bond with Cys797 within the EGFR active site and have revealed preclinical activity against T790M-containing mutants of EGFR [9]. However, wild-type EGFR and EGFR T790M mutant share highly similar three-dimensional structures and virtually identical binding affinities with ATP. Consequently, almost all of the reported, irreversible EGFR inhibitors displayed equal potencies against T790M mutant and wild-type enzyme, highlighting the current challenge in the search for EGFR ${ }^{\mathrm{T} 790 \mathrm{M}}$ mutant-selective inhibitors [10,11]. WZ4002 (3) [12], rociletinib (4) [13], and osimertinib (5) $[14,15]$ are typical EGFR T790M inhibitors and a phase trial has revealed capability in gefitinib-resistant NSCLC patients who suffer from EGFR mutations (Figure 1). Unfortunately, only osimertinib possesses exceptional biological properties, and has thus been approved in 2015 for the treatment of patients with metastatic EGFR T790M mutation-positive NSCLC [16]. On the basis of considerable efforts to identify more effective and safe agents to overcome gefitinib-produced resistances [17-19], we found the novel diphenylpyrimidine derivative $\mathrm{N}$-(3-((5-chloro-2-(4-((1-morpholino)methyl)phenylamino)-4-pyrimidinyl)amino)phenyl)acrylamide (6, DY3002, Figure 2) [20]. The molecule displayed enhanced activity and increased selectivity against EGFR $^{\mathrm{T} 790 \mathrm{M}}$ and was thus reported as a promising NSCLC clinical candidate.

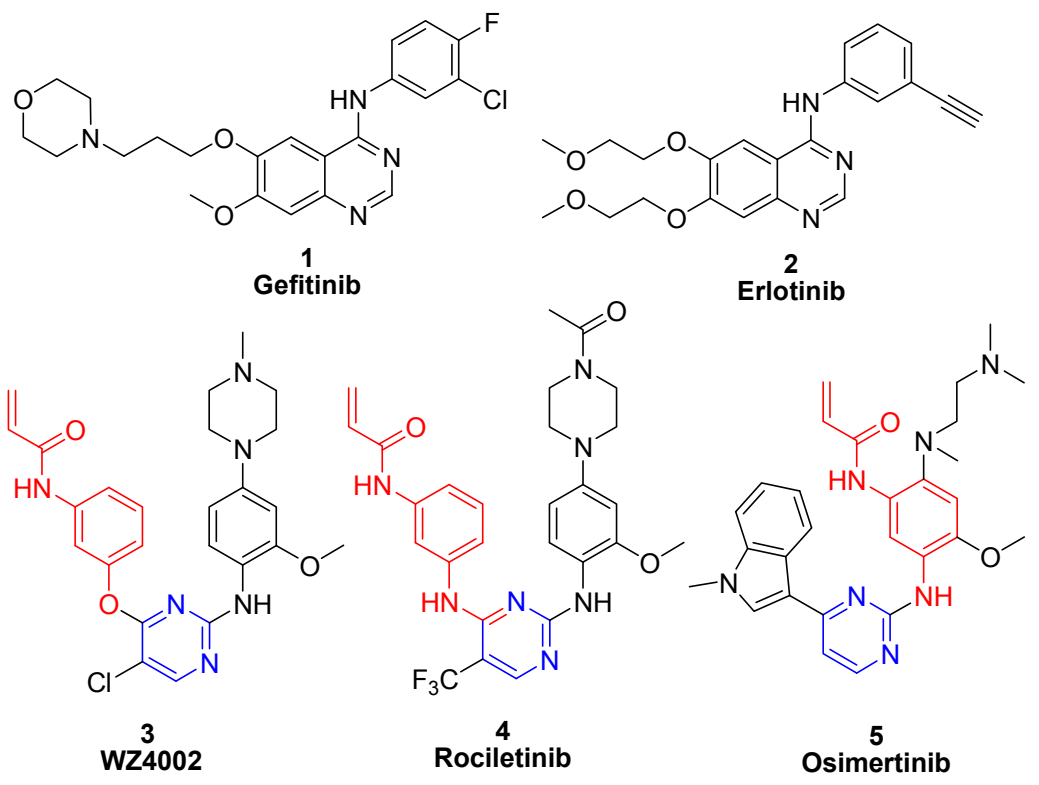

Figure 1. Structures of novel EGFR inhibitors.

A

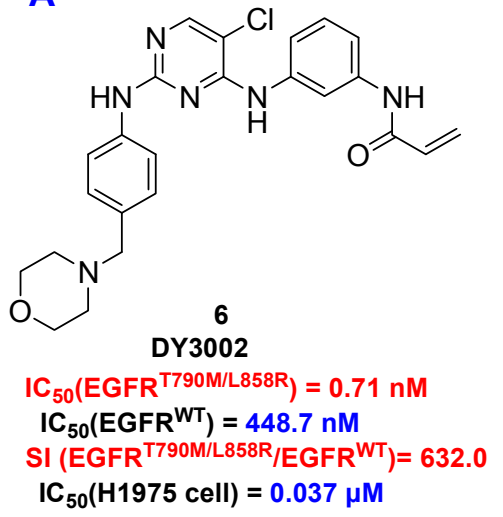

B

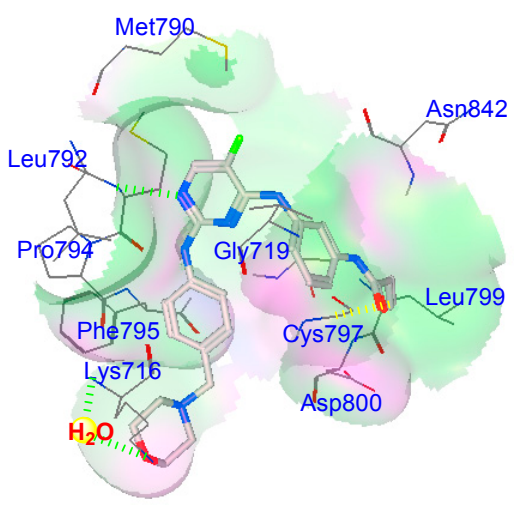

Figure 2. Structure of DY3002 (A) and its putative binding mode with EGFR ${ }^{\mathrm{T} 790 \mathrm{M}}$ enzyme (B). 


\section{Results and Discussion}

\subsection{Inhibition of Kinase and Cancer Cell Viability}

As shown in Table 1, DY3002 strongly inhibited EGFR ${ }^{\mathrm{T} 790 \mathrm{M} / \mathrm{L} 858 \mathrm{R}}$ enzyme activity at a surprisingly low concentration of $0.71 \mathrm{nM}$. In contrast, high concentrations $(460.2 \mathrm{nM})$ are necessary to interfere with wild-type EGFR. Thus, DY3002 possesses a 632.0-fold higher selectivity against EGFR ${ }^{\mathrm{T} 790 \mathrm{M} / \mathrm{L} 858 \mathrm{R}}$ mutants that against wild-type EGFR, suggesting that it will reduce side effects, such as the hyperglycemia problem. Compared to rociletinib $(S I=21.4)$ and osimertinib $(S I=40.9)$, DY3002 features approximately 15- and 30-fold higher selectivity, respectively. Motivated by this excellent activity, DY3002 was also evaluated in vitro for activity against a series of lung cancer cell lines, including H1975 ${ }^{\mathrm{T} 790 \mathrm{M}}$, HCC827 $7^{\text {del E746_A750 }}$, A431 wild-type, H1299wild-type, and A549 $^{\text {wild-type and k-ras }}$. Additionally, normal human bronchial cell line (HBE) and normal liver cell line (LO-2) were also tested to explore cytotoxicity on cellular level using CCK-8 assay method. The results are presented in Table 2 and indicate that DY3002 features strong activity $\left(\mathrm{IC}_{50}=0.037 \mu \mathrm{M}\right)$ against $\mathrm{H} 1975$ cells with EGFR $^{\mathrm{T} 790 \mathrm{M}}$ compared to reference compounds. Yet, it only moderately inhibited proliferations of the wild type cell lines A431, H1299, LoVo, and A549 with $\mathrm{IC}_{50}$ values of $0.382 \mu \mathrm{M}, 4.12 \mu \mathrm{M}, 2.46 \mu \mathrm{M}$, and $4.45 \mu \mathrm{M}$, respectively. For activity against HCC827 cells with EGFR del E746_A750, all these inhibitors are potent, with $\mathrm{IC}_{50}$ values of approximately $0.010 \mu \mathrm{M}$. Fortunately, DY3002 is not sensitive to normal cell lines LO-2 $\left(\mathrm{IC}_{50}=4.24 \mu \mathrm{M}\right)$ and $\mathrm{HBE}\left(\mathrm{IC}_{50}>40.0 \mu \mathrm{M}\right)$, suggesting low cell cytotoxicity. Figure 3, reveals remarkable inhibition of A431 cells and H1975 cells proliferations increasing DY3002 concentrations with a range from 25 to $400 \mathrm{nmol} / \mathrm{L}$, and $0.3125 \mu \mathrm{M}$ to $10 \mu \mathrm{M}$, respectively. AO/EB and DAPI staining assays were carried out to investigate the apoptotic morphology of cancer cells. As shown in Figure 4, subsequent to AO/EB or DAPI staining, both EGFR ${ }^{\mathrm{T} 790 \mathrm{M}}$-mutated H1975 cells and wild-type EGFR-mutated A431 cells that were exposed to DY3002 revealed striking nuclear condensation, membrane blebbing, nuclear fragmentation, and apoptotic bodies, all of which are characteristics of apoptotic programmed cell death.

Table 1. In vitro EGFR tyrosine kinases (wild-type and L858R/T790M mutation) activities ${ }^{\text {a }}$.

\begin{tabular}{cccc}
\hline \multirow{2}{*}{ Compounds } & \multicolumn{2}{c}{ EGFR $\left(\mathbf{I C}_{\mathbf{5 0}, \mathbf{n M})}{ }^{\mathbf{b}}\right.$} & \multirow{2}{*}{ SI(WT:L858R/T790M) } \\
\cline { 2 - 3 } & $\mathbf{W T}$ & L858R/T790M & \\
\hline DY3002 & 448.7 & 0.71 & 632.0 \\
Rociletinib & 460.2 & 21.5 & 21.4 \\
Osimertinib & 482.3 & 11.8 & 40.9 \\
Gefitinib & 15.5 & 823.3 & - \\
\hline
\end{tabular}

a Data represent the mean of at least three separate experiments; ${ }^{b}$ Concentration needed to inhibit the autophosphorylation of the cytoplasmic domain of EGFR by 50\%, as calculated using GraphPad Prim version 5.0 (GraphPad Software, Inc., La Jolla, CA, USA).

Table 2. Cellular antiproliferative activities ${ }^{a}$.

\begin{tabular}{ccccccccc}
\hline \multirow{2}{*}{ Compounds } & \multicolumn{7}{c}{ Cellular Antiproliferative Activity $\left(\mathrm{IC}_{\mathbf{5 0}}, \boldsymbol{\mu M}\right)$} \\
& H1975 & HCC827 & $\mathbf{~ A 4 3 1}$ & H1299 & LoVo & A549 & LO-2 & HBE \\
\hline DY3002 & 0.037 & 0.0104 & 0.382 & 4.12 & 2.46 & 4.45 & 4.24 & $>40.0$ \\
Rociletinib & 0.137 & 0.0181 & 1.29 & 20.1 & 20.1 & 6.50 & 8.57 & $>40.0$ \\
Osimertinib & 0.087 & 0.0102 & 0.915 & 7.49 & 4.85 & 7.28 & 4.56 & 8.39 \\
Gefitinib & 10.8 & 0.0106 & 3.30 & 10.8 & 13.2 & 29.4 & 14.5 & 23.8 \\
\hline
\end{tabular}

${ }^{a}$ Data represent the mean of at least three separate experiments; ${ }^{\mathrm{b}}$ The $\mathrm{IC}_{50}$ values are the concentrations in micromolar needed to inhibit cell growth by $50 \%$ as calculated using GraphPad Prim version 5.0. 

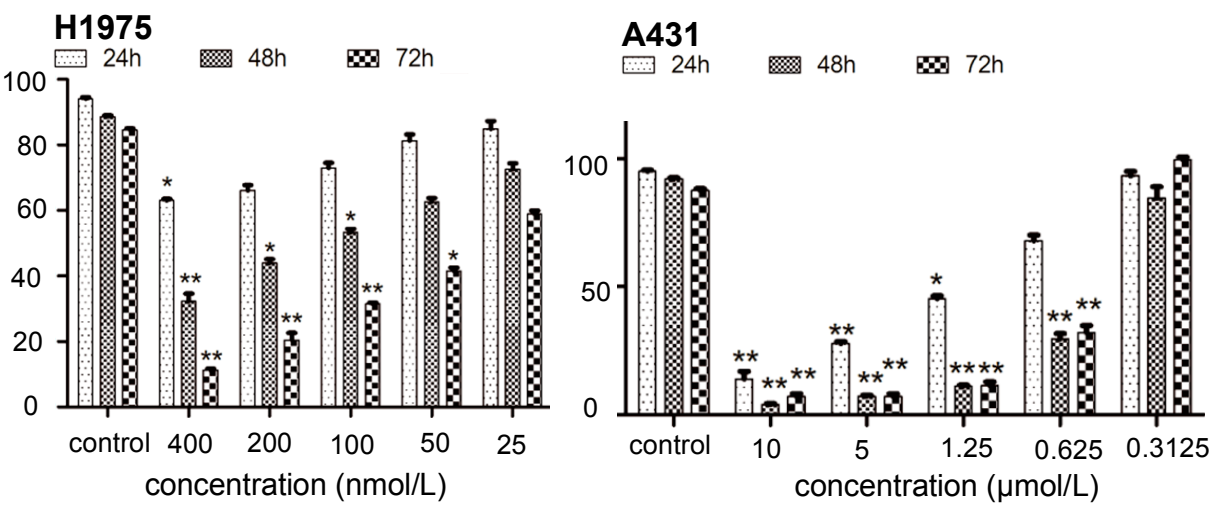

Figure 3. The effects of treating time and concentrations of DY3002 on cell viability. ${ }^{*} p<0.05$; ** $p<0.01$.

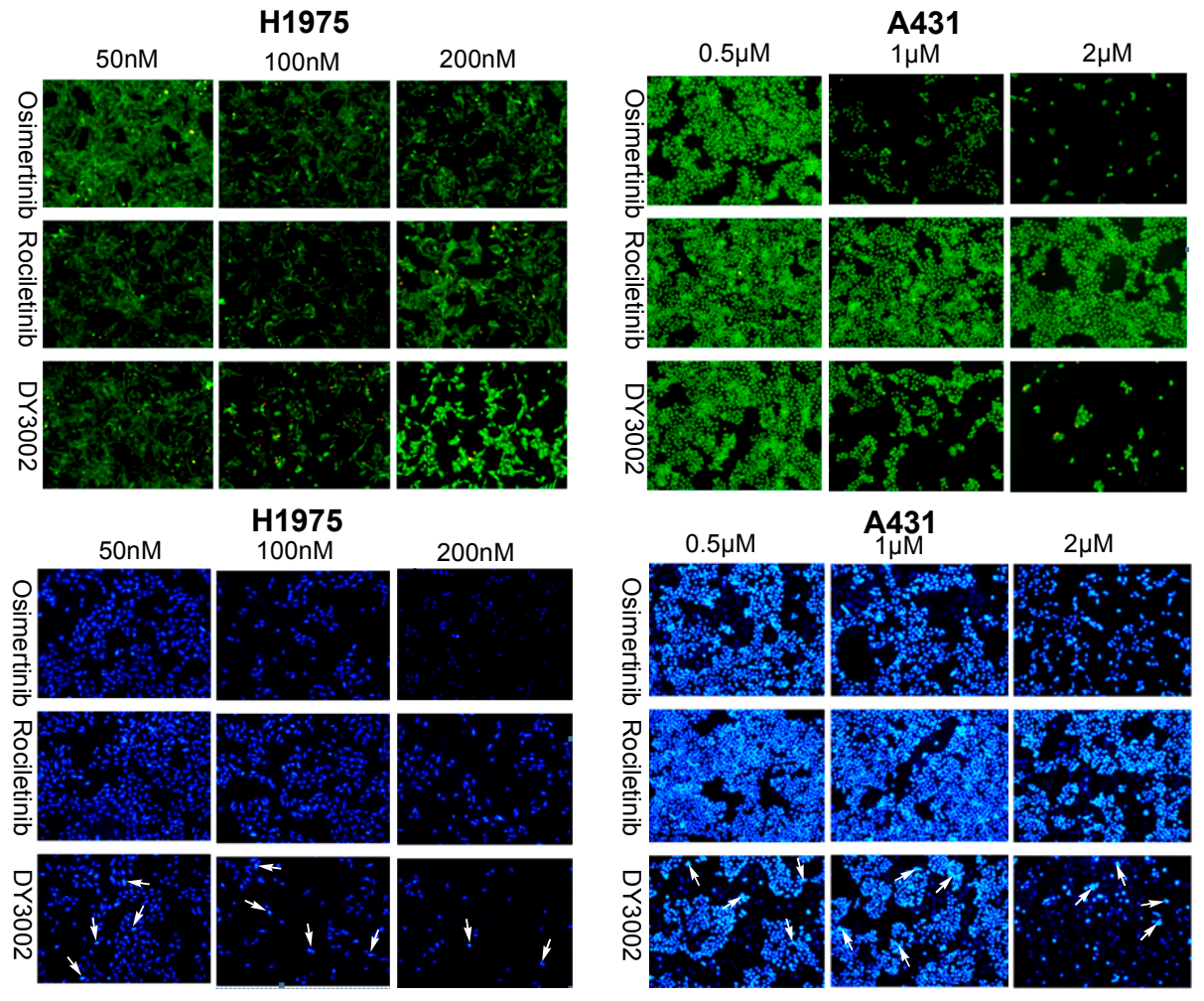

Figure 4. Morphological changes of $\mathrm{H} 1975$ and A431 cells $(100 \times$, final magnification, green images: AO/EB double fluorescent staining of H1975 and A431 cells treated with different concentrations of osimertinib, rociletinib, and DY3002 for 48 h, blue images: DAPI staining of H1975 and A431 cells treated with different concentrations of osimertinib, rociletinib, and DY3002 for $48 \mathrm{~h}$ ). White arrows represented typical apoptotic cancer cells.

\subsection{Wound Healing and Transwell Assays}

To determine if DY3002 can prevent A431 and H1975 cell migration, wound healing and transwell assays were performed. As indicated in Figures 5 and 6, DY3002 could strongly inhibit migration of H1975 cells, but only moderately interfered with A431 cells. Below concentrations of $200 \mathrm{nM}$, DY3002 is equivalent to osimertinib and rociletinib in inhibiting the migration of H1975 cells; however, interference with A431 cells is weaker compared to osimertinib. These results are in accordance with explorations based on CCK-8 assays, indicating a slightly lower selectivity of DY3002 compared to osimertinib against resistant $\mathrm{H} 1975$ cells over wild-type A431 cells. 

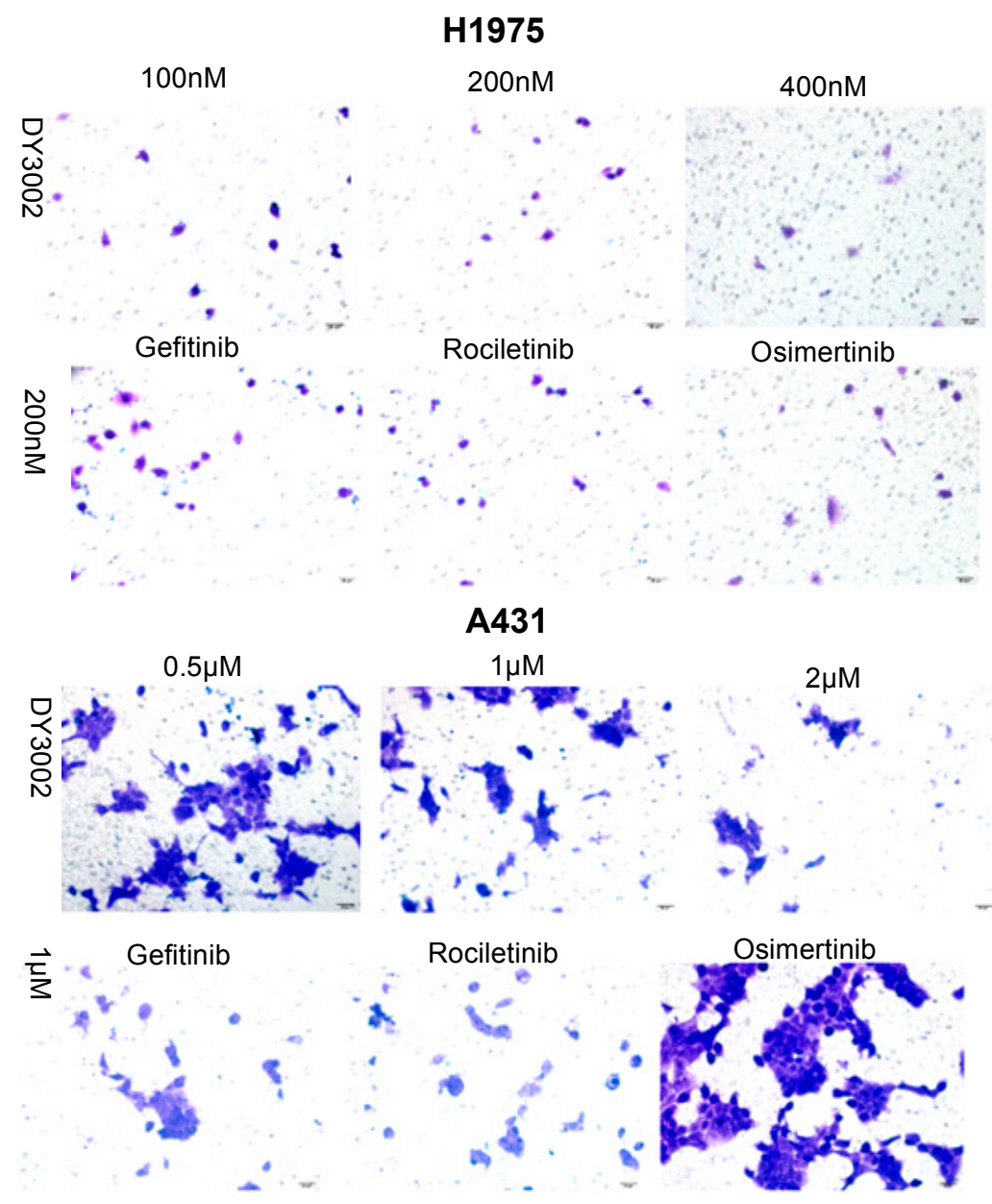

Figure 5. Representative images of H1975 and A431 cells treated with DY3002, rociletinib, and osimertinib by the transwell invasion assay.
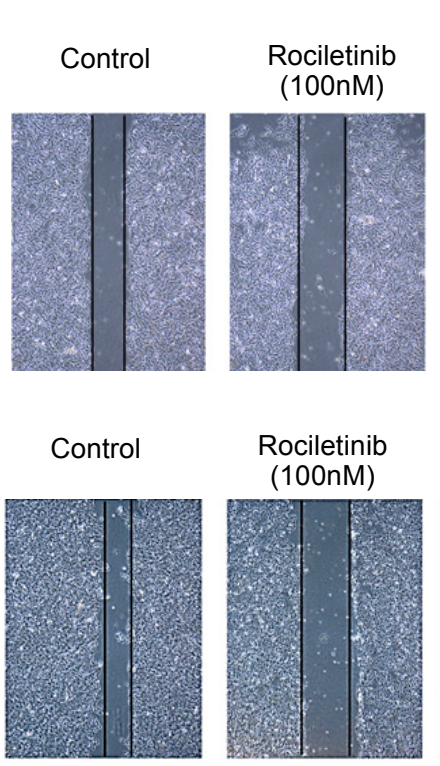

H1975

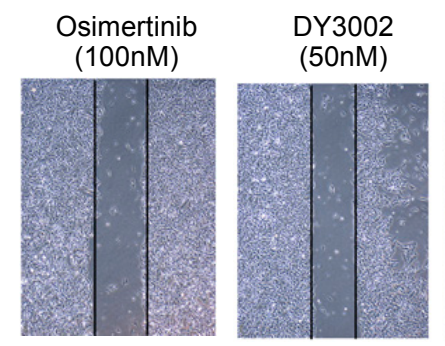

A431
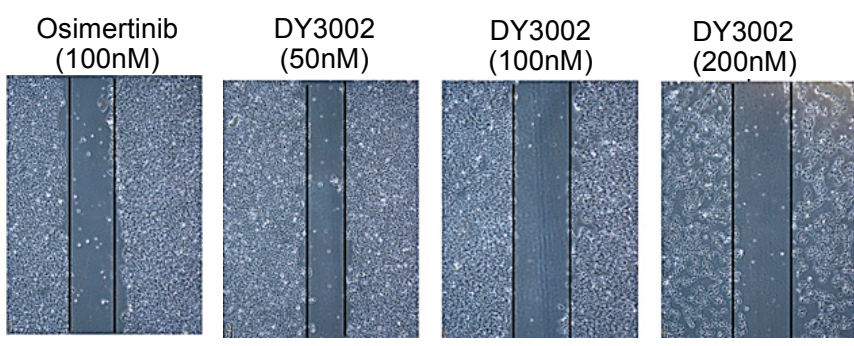

Figure 6. Representative images of $\mathrm{H} 1975$ and A431 cells treated with different concentrations of DY3002, rociletinib, and osimertinib for $48 \mathrm{~h}$ by the wound-healing assay. 


\subsection{Effects on ROS Levels}

An emerging theme in signal transduction research via growth factor receptors and adhesion molecules is the role of reactive oxygen species (ROS). Hydrogen peroxide $\left(\mathrm{H}_{2} \mathrm{O}_{2}\right)$ in particular is an essential downstream intermediate, modulating cell responses via transient and reversible oxidation of key intracellular signaling components [21]. Consequently, DY3002 had an effect on ROS generation in H1975 and A431 cells (Figure 7). In fact, DY3002, rociletinib, and osimertinib effectively inhibited ROS generation in both A431 and H1975 cells. Moreover, this assay revealed that all of the tested treatment options are more sensitive to H1975 cells with T790M mutation than to wild-type A431 cells.
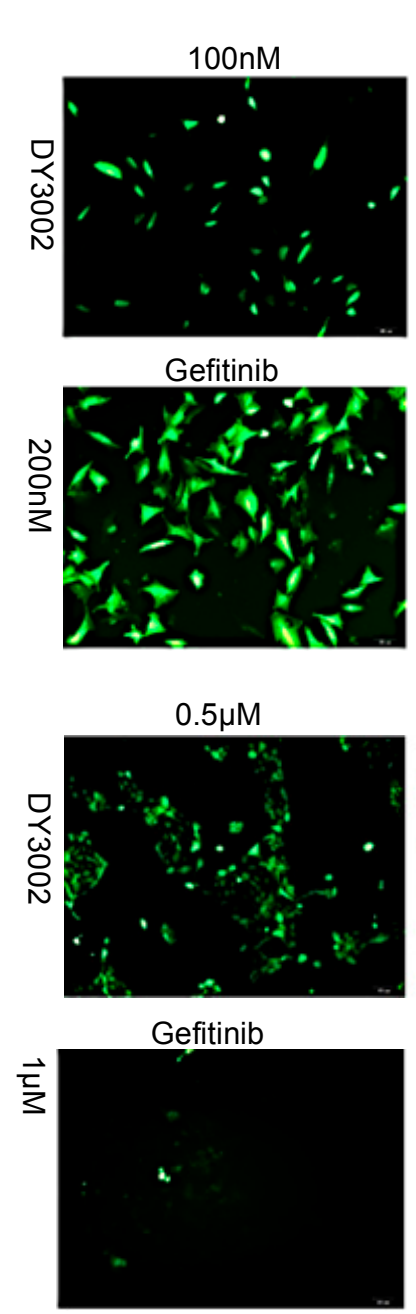

\section{H1975}
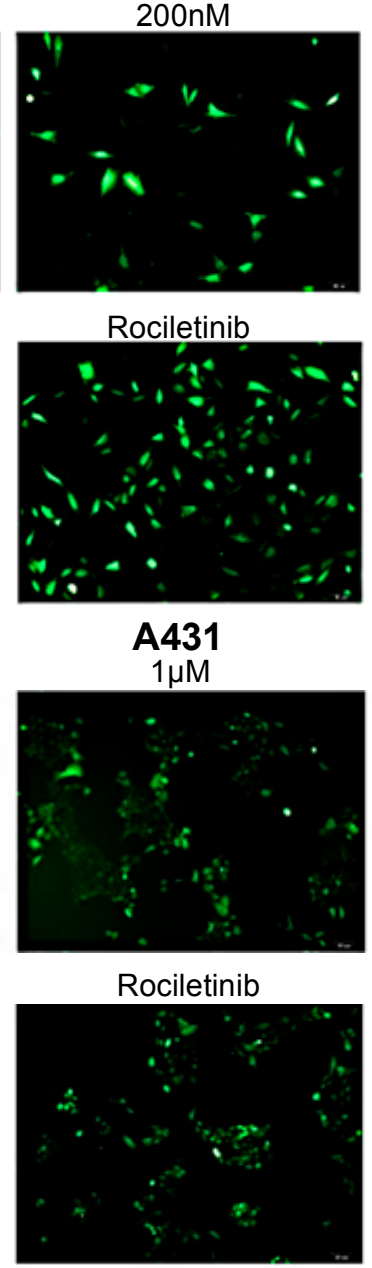

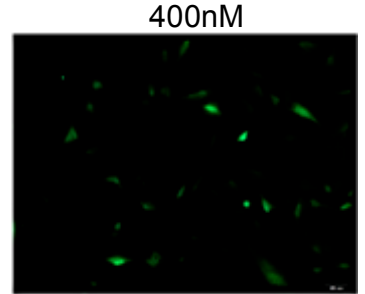

Osimertinib

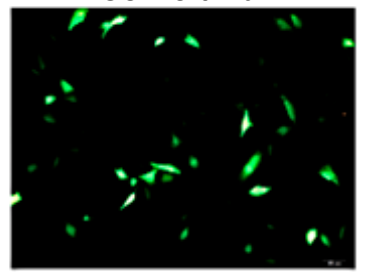

$2 \mu \mathrm{M}$
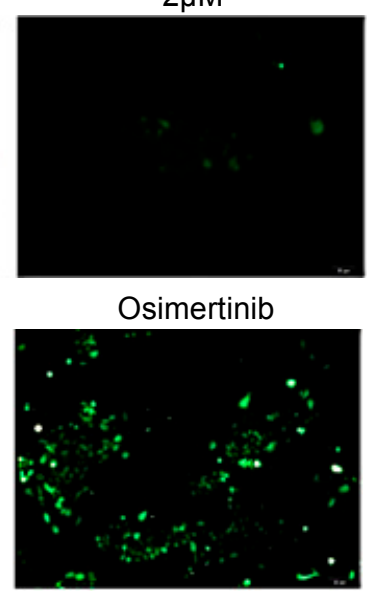

Figure 7. Representative images of H1975 and A431 cells treated with DY3002, rociletinib, and osimertinib by the ROS detection. Cells were treated with different concentrations of inhibitors for $24 \mathrm{~h}$, then the cells were harvested, resuspended in $1 \mathrm{~mL}$ of DCFH-DA (10 mM), and detected the levels of ROS.

\subsection{Flow Cytometer Analysis}

As shown in Figure 8, DY3002 triggered apoptosis in EGFR ${ }^{\mathrm{T} 90 \mathrm{M}}$-mutated $\mathrm{H} 1975$ cells in a dose- and time-dependent manner. Apoptosis rates remarkably increased from $25.7 \%$ to $90.1 \%$ in H1975 cells treated with DY3002 (100 nM, $200 \mathrm{nM}$, and $400 \mathrm{nM})$ for $48 \mathrm{~h}$. At identical concentration (200 nM), the apoptosis rate of DY3002 (72.0\%) was slightly higher compared to rociletinib $(65.2 \%)$, while it is much higher compared to gefitinib (4.6\%). For A431 cells, the percentages of apoptotic cells clearly increased from $46.1 \%$ to $61.6 \%$ via DY3002 treatment $(0.5 \mu \mathrm{M}, 1 \mu \mathrm{M}$, and $2 \mu \mathrm{M})$ for 
48 h. Compared to gefitinib (61.6\%), both DY3002 (50.8\%), and rociletinib (54.5\%) possess decreased apoptosis rates.

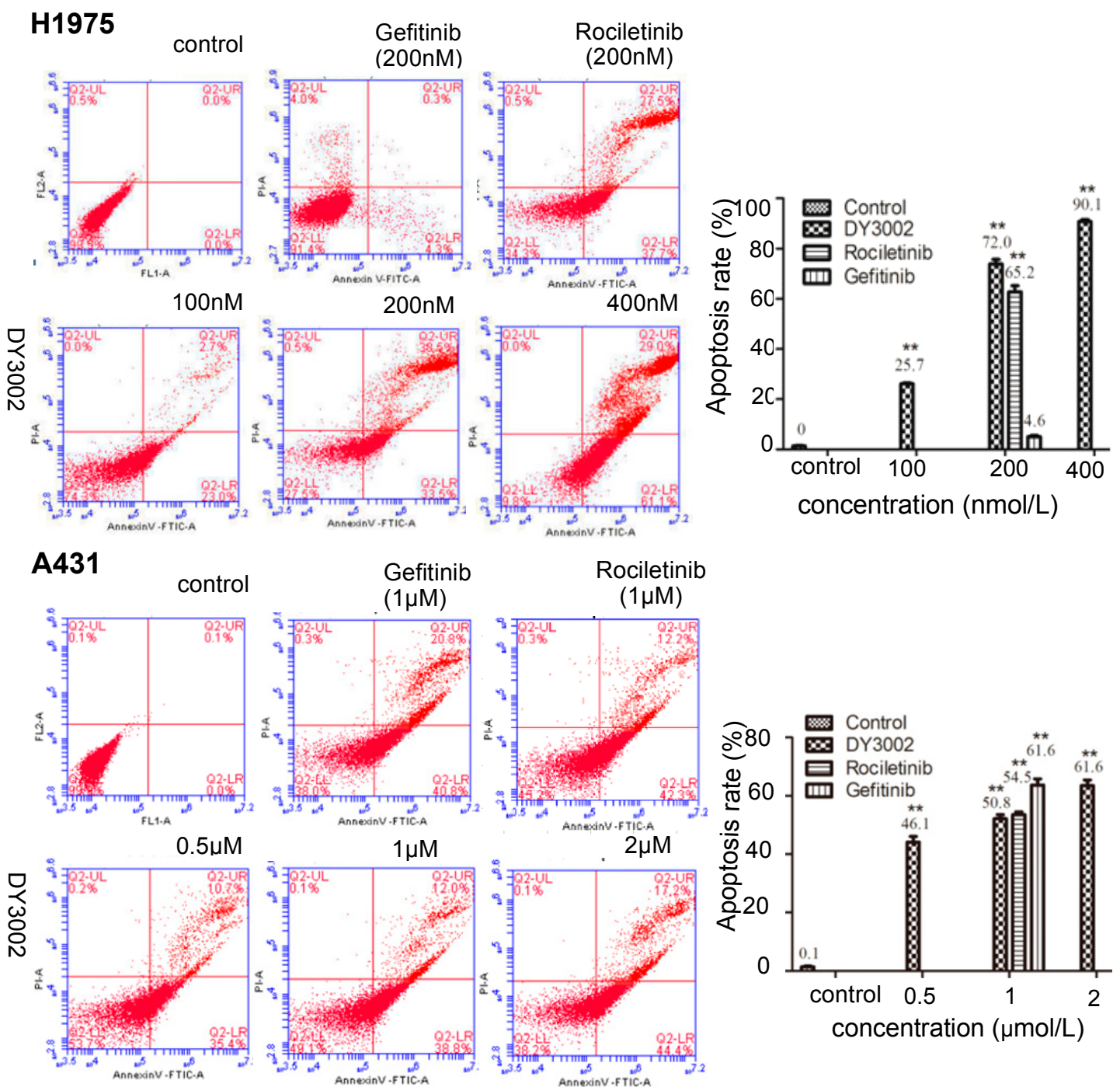

Figure 8. Effects of DY3002, rociletinib, and gefitinib on A431 and H1975 cells cycle arrest detected by flow cytometry assay. Cells were treated by different concentrations of inhibitors for $48 \mathrm{~h}$, then were stained with Annexin V-FITC/propidium iodide and analyzed by flow cytometry assay. Results are representative of three separate experiments, dates are expressed as the mean \pm standard deviation, ** $p<0.01$.

To investigate the effects of DY3002 on cell-cycle progressions in H1975 and A431 cells, we measured DNA content of cancer cells that were treated with DY3002 and reference compounds using a flow cytometer. Representative diagrams are shown in Figure 9. Evidently, DY3002 significantly locked H1975 cells at the S phase. Compared to control group, the percentages of the G0/G1 phase increased from $51.16 \%$ to $91.33 \%$, and those of the S phase decreased from $37.17 \%$ to $5.67 \%$ via treatment with DY3002 at concentrations from $100 \mathrm{nM}, 200 \mathrm{nM}$, and $400 \mathrm{nM}$ for $48 \mathrm{~h}$. However, the percentages of the G2/M phase had only minor changes. For A431 cells, the proportion of the G0/G1 phase increased from $65.53 \%$ to $75.87 \%$ subsequent to treatment of the cancer cells with DY3002 $(0.5 \mu \mathrm{M}$, $1 \mu \mathrm{M}$, and $2 \mu \mathrm{M}$ ) for $48 \mathrm{~h}$, revealing that DY3002 could cause a G0/G1 arrest in A431 cells. 


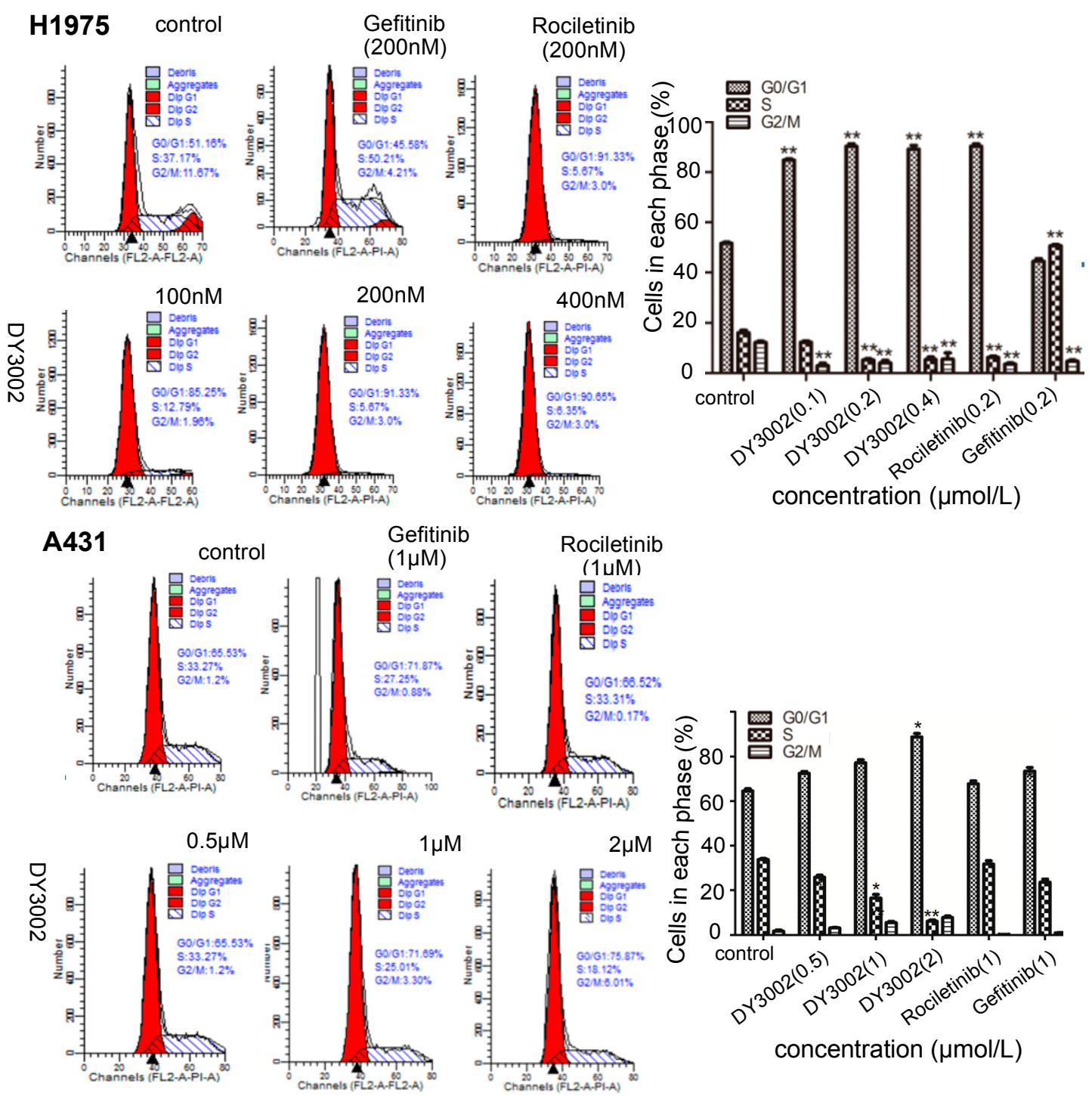

Figure 9. Effects of DY3002, rociletinib, and gefitinib on H1975 and A431 cells cycle arrest detected by flow cytometry assay. Cells were treated with different concentrations of inhibitors for $48 \mathrm{~h}$, collected and fixed with $70 \%$ ethanol at $4{ }^{\circ} \mathrm{C}$ overnight. Then, the cells were stained by the mixture containing $5 \mathrm{~mL}$ propidium iodide for $10 \mathrm{~min}$ at $37^{\circ} \mathrm{C}$, and the cell cycle was analyzed by a flow cytometer. ${ }^{*} p<0.05 ;{ }^{* *} p<0.01$.

\subsection{Molecular Simulation}

In addition, DY3002 was docked into the ATP-binding site in a model of EGFR kinase with T790M mutation (PDB code: 3IKA) to explore its putative interaction mechanism [12]. We applied AutoDock 4.2 in parallel with default parameters [22,23]. The results are shown in Figure 2B, revealing DY3002 to form several strong interactions with EGFR ${ }^{\mathrm{T} 790 \mathrm{M}}$, including: (1) a covalent bond between the acryl amide functionality with the amino acid Cys797; (2) a strong contact generated from the chlorine atom at the $C-5$ position of the pyrimidine core with mutant gatekeeper residue Met790; (3) strong hydrogen bonds between the $\mathrm{N}-1$ nitrogen atom of the pyrimidine core and the amino acid Leu792, as well as the oxygen atom of the morpholine ring with Lys716 through a water molecule. Through these strong contacts, DY3002 robustly interacts with the EGFR ${ }^{\mathrm{T} 790 \mathrm{M}}$ enzyme, in accordance with the observed strong anti-EGFR ${ }^{\mathrm{T} 790 \mathrm{M}}$ activity. 


\subsection{In Vivo Blood Sugar Test}

As reported, rociletinib potentially produces a major side effect of hyperglycemia when administered in high dose to patients during clinical trails [24,25]. To confirm whether DY3002 will produce this effect in rats as well, the experiment is simply assessing glucose tolerance in healthy rats for which no positive control was performed. Rates were orally given compound DY3002 (HBr form, $50 \mathrm{mg} / \mathrm{kg}$ ) and a vehicle for comparison. Figure 10 confirms that DY3002 did not yield hyperglycemia compared to control group at high drug doses in healthy rats, indicating low toxicity and consequent suitability for further development.

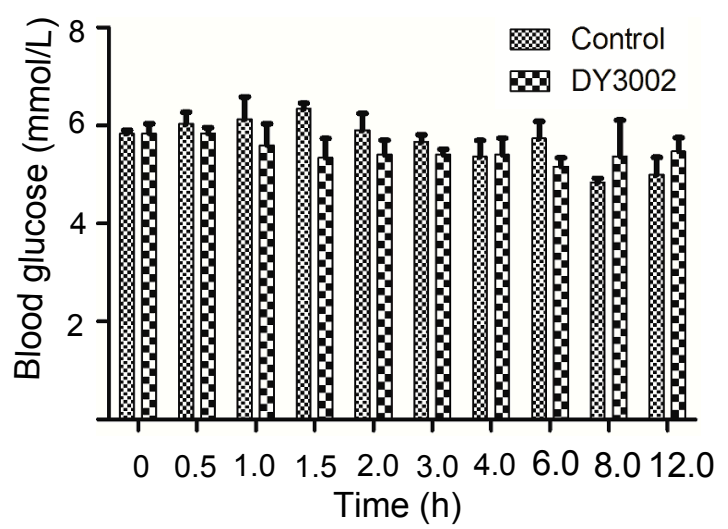

\begin{tabular}{|c|c|c|c|c|c|c|c|c|c|c|c|c|}
\hline Time (h) & & & 0 & 0.5 & 1 & 1.5 & 2 & 3 & 4 & 6 & 8 & 12 \\
\hline \multirow{6}{*}{ Blood Glucose (mmol/L) } & \multirow{3}{*}{ Blank } & 1 & 5.7 & 5.6 & 7.0 & 6.5 & 5.2 & 5.7 & 4.9 & 5.2 & 4.7 & 4.6 \\
\hline & & 2 & 5.9 & 6.4 & 5.9 & 6.1 & 6.7 & 5.4 & 6.0 & 6.4 & 4.8 & 4.7 \\
\hline & & 3 & 5.9 & 6.1 & 5.5 & 5.4 & 6.3 & 5.9 & 5.2 & 5.6 & 5.0 & 5.7 \\
\hline & \multirow{3}{*}{ DY3002 } & 1 & 6.2 & 5.9 & 6.3 & 6.0 & 4.8 & 5.4 & 4.8 & 5.5 & 6.3 & 5.8 \\
\hline & & 2 & 5.8 & 5.6 & 5.7 & 5.4 & 5.8 & 5.6 & 6.0 & 4.9 & 5.9 & 5.7 \\
\hline & & 3 & 5.5 & 6.0 & 4.8 & 4.6 & 5.6 & 5.2 & 5.4 & 5.1 & 3.9 & 4.9 \\
\hline
\end{tabular}

Figure 10. The effects of DY3002 on the blood glucose concentration in a rat model.

\section{Materials and Methods}

\subsection{Cell Culture and Reagents}

H1975, HCC827, A549, and H1299 human NSCLC adenocarcinoma cells were obtained from the American Type Culture Collection. A431 human epidermoid carcinoma cells were kind gifts from Fuheng Biology Company (Shanghai, China). LoVo human colon carcinoma cells, HBE human bronchial epithelioid cells, LO-2 human normal hepatocyte cells were kind gifts from YuXi Biotech Company (Jiangsu Province, China). The Cell Counting Kit-8 (CCK-8) reagent was obtained from Biotool Company (Kirchberg, Switzerland). The wild-type EGFR enzyme, mutant EGFR L858R/T790M enzyme, and the ADP-Glo ${ }^{\mathrm{TM}}$ Kinase Assay system that measures ADP formed from a kinase reaction were purchased from Promega Corporation (Fitchburg, WI, USA). The Annexin V-FITC Apoptosis Detection Kit and Cell Cycle Assay were purchased from Beyotime Company (Shanghai, China). H1975, HCC827, and H1299 cells were grown in RPMI-1640 (Gibco ${ }^{\circledR}$, Big Cabin, OK, USA) supplemented with 10\% FBS (Gibco ${ }^{\circledR}$ ) and 1\% penicillin-streptomycin (Beyotime Company, Shanghai, China). A431, LoVo, HBE, and LO-2 cells were grown in DMEM $\left(\mathrm{Gibco}^{\circledR}\right)$ supplemented with $10 \%$ FBS $\left(\mathrm{Gibco}^{\circledR}\right)$ and $1 \%$ penicillin-streptomycin (Beyotime Company, Shanghai, China). All cells were maintained and propagated as monolayer cultures at $37^{\circ} \mathrm{C}$ in humidified $5 \% \mathrm{CO}_{2}$ incubator. 


\subsection{Statistical Analysis Data}

Significant differences among groups were analyzed using the one-way ANOVA test. Duncan's multiple range test was used to determine the statistical significance $(p<0.01$ and $p<0.05)$ between control and DY3002-treated groups. All statistical analyses were performed with SPSS 17.0 software (SPSS Inc., Chicago, IL, USA).

\subsection{Biological Test Method}

\subsubsection{Kinase Enzymatic Assays}

The wild-type EGFR kinase enzyme system (Catalog. V3831) and the T790M/L858R-mutated EGFR kinase enzyme (Catalog. V5324) were purchased from Promega Corporation (Fitchburg, WI, USA). Concentrations consisting of suitable levels from 0.1 to $100 \mathrm{nM}$ were used for all of the tested compunds. The experiments were performed according to the instructions of the manufacturer. The more detailed and complete protocols, see the ADP-Glo ${ }^{\mathrm{TM}}$ kinase Assay Technical Manual \#313, and the active kinase datasheet available at: http:/ / www.promega.com/tbs/tm313/tm313/tm313.html and http://www.promega.com/KESProtocol (or http://www.promega.com/tbs/signaling.htm), respectively. The test was performed in a 384-well plate, and includes the major steps below: (1) perform a $5 \mu \mathrm{L}$ kinase reaction using $1 \times$ kinase buffer (e.g., $1 \times$ reaction buffer $\mathrm{A}$ ); (2) incubate at room temperature for $60 \mathrm{~min}$; (3) add $5 \mu \mathrm{L}$ of ADP-Glo ${ }^{\mathrm{TM}}$ Reagent to stop the kinase reaction and deplete the unconsumed ATP, leaving only ADP and a very low background of ATP; (4) incubate at room temperature for $40 \mathrm{~min}$; (5) add $10 \mu \mathrm{L}$ of Kinase Detection; (6) reagent to convert ADP to ATP and introduce luciferase and luciferin to detect ATP; (7) incubate at room temperature for $30 \mathrm{~min}$; (8) plate was measured on TriStar ${ }^{\circledR}$ LB942 Multimode Microplate Reader (BERTHOLD TECHNOLOGIES GmbH \& Co. KG., Bad Wildbad, Germany) to detect the luminescence (Integration time 0.5-1 s). Curve fitting and data presentations were performed using GraphPad Prism version 5.0 (GraphPad Software, Inc.).

\subsubsection{Cell Growth Inhibitory Activity}

\section{CCK-8 Assay}

All the cell viability assays were performed according to the CCK-8 method. The cells were seeded at a density of 5 to $8 \times 10^{4}$ cells $/ \mathrm{mL}$ in 96-well plates in growth medium supplemented with $10 \%$ serum at $37{ }^{\circ} \mathrm{C}$ with $5 \% \mathrm{CO}_{2}$ for one day. After $12 \mathrm{~h}$ of incubation, $100 \mu \mathrm{L}$ of medium was removed, and $100 \mu \mathrm{L}$ of sample solution with different concentrations of inhibitor was added and then the cells were incubated for 48 or $72 \mathrm{~h}$. Subsequently, $10 \mu \mathrm{L}$ of CCK-8 reagent (Biotool Company, Kirchberg, Switzerland, $5.0 \mathrm{mg} / \mathrm{mL}$ ) dissolved in phosphate-buffered saline (PBS) was added and the cells were incubated for another $4 \mathrm{~h}$. The absorbance was read at $450 \mathrm{~nm}$ with a microplate reader (Thermo Fisher Scientific, Waltham, MA, USA). The data were calculated using GraphPad Prim version 5.0.

\section{AO/EB and DAPI Staining Assay}

Approximately $2 \times 10^{5}$ cells/well of A431 and H1975 cells in 6-well plates were incubated in an incubator for $48 \mathrm{~h}$, then treated with different concentrations of inhibitors for $48 \mathrm{~h}$. After incubation, the cells were washed with PBS twice. Then, total of $20 \mu \mathrm{L}$ of the solution containing the AO/EB dye mix $(1.0 \mu \mathrm{g} / \mathrm{mL}$ of $\mathrm{AO}$ and $1.0 \mu \mathrm{g} / \mathrm{mL}$ of EB in PBS) was added to the cells. The apoptotic, necrotic, and live cells were observed and counted under the fluorescent microscope (OLYMPUS, Tokyo, Japan). DAPI staining was performed after being treated as mentioned above. The cells plated in 6-well plates were washed twice with PBS and fixed with $10 \%$ formaldehyde for $10 \mathrm{~min}$, then washed with PBS three times. Cells were subsequently incubated in DAPI $(1.0 \mu \mathrm{g} / \mathrm{mL})$ solution at room temperature for $10 \mathrm{~min}$, washed with PBS and examined under a fluorescence microscope (OLYMPUS). 


\subsubsection{Wound-Healing Assay}

The cancer cells were cultured in 6-well plates for $48 \mathrm{~h}$ at $37^{\circ} \mathrm{C}$. Wounds were created in the cell monolayer and washed with PBS to remove cell debris, then the cells were treated with different concentrations of inhibitor for $48 \mathrm{~h}$. After that, the dead cells were washed away with PBS, and the images were taken by the fluorescence microscope (OLYMPUS).

\subsubsection{Transwell Invasion Assay}

Cell migration assay was evaluated by using Boyden chambers containing a transwell membrane filter with an $8 \mu \mathrm{m}$ size pore (Corning Costa Corp, Cambridge, MA, USA). Prior to the invasion assay, the filter membrane was coated with $60 \mu \mathrm{L}$ of Matrigel (BD Biosciences, Billerica, MA, USA) at a $1: 8$ dilution and rehydrated by adding $0.5 \mathrm{M}$ serum-free medium to the apical side of the chamber at $37^{\circ} \mathrm{C}$ for $0.5 \mathrm{~h}$. The cells $\left(2 \times 10^{5}\right.$ cells / well for invasion assay) were seeded to the apical side of the chamber with $200 \mu \mathrm{L}$ medium with different concentrations of inhibitors, and the basolateral side of the chamber was filled with $600 \mu \mathrm{L}$ medium containing $10 \% \mathrm{FBS}$. After $24 \mathrm{~h}$ at $37^{\circ} \mathrm{C}$, the cells adherent to the upper surface of the filter were swept by cotton swabs, then fixed with methanol, stained with crystal violet, and the cells were counted under a microscope in five random fields, irrespective of staining intensity. The images were taken by the fluorescence microscope (OLYMPUS).

\subsubsection{Detection of Intracellular ROS Generation}

The human H1975 and A431 cells at a density of approximately $2 \times 10^{5}$ cells/well were plated in a 6-well plate and then treated with different concentrations of inhibitors for $24 \mathrm{~h}$. Then the cells were harvested, resuspended in $1 \mathrm{~mL}$ of DCFH-DA $(10 \mathrm{mM})$, and the levels of ROS were determined by flow cytometry (Becton-Dickinson, Franklin Lakes, NJ, USA).

\subsubsection{Cell Apoptosis}

The H1975 and A431 cells ( 1 to $5 \times 10^{5}$ cells/well) incubated in 6-well plates were treated by different concentrations of inhibitors for $48 \mathrm{~h}$. Then, they were collected and fixed with $70 \%$ ethanol at $4{ }^{\circ} \mathrm{C}$ overnight. After beening fixed with $75 \%$ ethanol at $4{ }^{\circ} \mathrm{C}$ for $24 \mathrm{~h}$, the cells were stained with Annexin V-FITC $(5 \mu \mathrm{L}) /$ propidium iodide $(5 \mu \mathrm{L})$ and analyzed by flow cytometry assay (Becton-Dickinson, Franklin Lakes, NJ, USA).

\subsubsection{Cell Cycle Analysis}

The H1975 and A431 cells at a density of approximately $2 \times 10^{5}$ cells/well were incubated in 6-well plates, treated with different concentrations of inhibitors for $48 \mathrm{~h}$, collected and fixed with $70 \%$ ethanol at $4{ }^{\circ} \mathrm{C}$ overnight. After fixation, the cells were washed with PBS and stained with propidium iodide (PI) for $10 \mathrm{~min}$ under subdued light. Stained cells were analyzed by flow cytometry assay (Becton-Dickinson, Franklin Lakes, NJ, USA).

\subsubsection{Glucose Concentration Determination}

The Roche Accu-chek ${ }^{\circledR}$ Go blood meter was used for the determination of glucose concentration. Before testing, standard set-up of blood meter was performed according to the instrument's specifications. The meter displays the blood sugar level in units of mmol/L. Male SD rates (180-220 g) were fasted overnight prior to dosing the next morning. Water was allowed ad libitum throughout the study. Rats were orally given compound DY3002 $(50 \mathrm{mg} / \mathrm{kg})$ and a vehicle. For the oral study, the compounds were formulated as a solution (Solutol HS15: NS = 30:70, v:v). Sampling occurred prior to dosing and at 7-9 different time points up to $12 \mathrm{~h}$. Concentration of glucose in the blood was determined by blood meter. 


\subsection{Molecular Modeling}

Docking studies were carried out on AutoDock 4.2 (The Scripps Research Institute, MB-5, y, La Jolla, CA, USA). The crystal structure (PDB: 3IKA) of the kinase domain of EGFR ${ }^{\mathrm{T} 790 \mathrm{M}}$ bound to inhibitor 3 was used in the docking studies. The enzyme preparation and the hydrogen atoms addition was performed in the preparation process. The whole EGFR enzyme was defined as a receptor and the site sphere was selected on the basis of the binding location of WZ4002. By moving WZ4002 and the irrelevant water, molecule DY3002 was placed. The binding interaction energy was calculated to include Van der Waals, electrostatic, and torsional energy terms defined in the tripos force field. The structure optimization was performed using a genetic algorithm, and only the best-scoring ligand protein complexes were kept for analyses. The WWW site also includes many resources for use of AutoDock, including detailed tutorials that guide users through basic AutoDock usage, docking with flexible rings, and virtual screening with AutoDock. Tutorials may be found at: http:/ / autodock.scripps.edu/faqs-help/tutorial.

\section{Conclusions}

In conclusion, we report the novel mutant selective inhibitor DY3002 that targets both sensitizing mutations and T790M resistance mutation, while leaving the wild-type form of the receptor unaffected. These explorations revealed DY3002 to effectively inhibit the EGFR ${ }^{\mathrm{T} 790 \mathrm{M} / \mathrm{L} 858 \mathrm{R}}$ enzyme at a surprisingly low concentration $(0.71 \mathrm{nM})$, while having moderate activity $\left(\mathrm{IC}_{50}=448.7 \mathrm{nM}\right)$ against wild-type EGFR. Compared to rociletinib $(S I=21.4)$ and osimertinib $(S I=40.9)$, DY3002 significantly increased selectivity $(\mathrm{SI}=632.0)$. In cell-based tests, DY3002 markedly inhibited the proliferation of H1975 cells, with an $\mathrm{IC}_{50}$ value of $0.037 \mu \mathrm{M}$. Moreover, the $\mathrm{AO} / \mathrm{EB}$ and DAPI staining assays, and flow cytometer analyses indicated superior biological properties of DY3002 compared to references. An in vivo test in rat oral glucose tolerance model, revealed no hyperglycemia side effects of DY3002 via administering high drug doses $(50 \mathrm{mg} / \mathrm{kg}$ ). In summary, we identified the novel molecule DY3002, which serves as a promising EGFR ${ }^{\mathrm{T} 790 \mathrm{M}}$ inhibitor with the potential to overcome NSCLC resistance.

Acknowledgments: We are grateful to the National Natural Science Foundation of China (No. 81402788), the project of family noninvasive mechanical ventilation system construction and promotion for AECOPD patients: Health and Family Planning Commission of Liaoning Province (NO. 2015B004), the Ph.D. Start-up Fund of Natural Science Foundation of Liaoning Province (No. 20141115), and the Cultivation Project of Youth Techstars, Dalian (2016RQ043) for the financial support of this research.

Author Contributions: J.K. and X.M. designed the study, Y.L. performed the experiments. Z.S. analyzed the data. Y.J. and Z.T. supervised the experimental work. All authors read and approved the final manuscript.

Conflicts of Interest: The authors declare no conflicts of interest.

\section{References and Notes}

1. Molina, J.R.; Yang, P.; Cassivi, S.D.; Schild, S.E.; Alex, A.; Adjei, A.A. Non-small cell lung cancer: Epidemiology, risk factors, treatment, and survivorship. Mayo Clin. Proc. 2008, 83, 584-594. [CrossRef]

2. Sharma, S.V.; Bell, D.W.; Settleman, J.; Haber, D.A. Epidermal growth factor receptor mutations in lung cancer. Nat. Rev. Cancer 2007, 7, 169-181. [CrossRef] [PubMed]

3. Vansteenkiste, J. Gefitinib (Iressa): A novel treatment for non-small cell lung cancer. Expert Rev. Anticancer Ther. 2004, 4, 5-17. [CrossRef] [PubMed]

4. Tiseo, M.; Loprevite, M.; Ardizzoni, A. Epidermal growth factor receptor inhibitors: A new prospective in the treatment of lung cancer. Curr. Med. Chem. Anti-Cancer Agents 2004, 4, 139-148. [CrossRef] [PubMed]

5. Bonomi, P. Erlotinib: A new therapeutic approach for non-small cell lung cancer. Expert Opin. Investig. Drugs 2003, 12, 1395-1401. [CrossRef] [PubMed]

6. Kobayashi, S.; Boggon, T.J.; Dayaram, T.; Jänne, P.A.; Kocher, O.; Meyerson, M.; Johnson, B.E.; Eck, M.J.; Tenen, D.G.; Halmos, B. EGFR mutation and resistance of non-small-cell lung cancer to gefitinib. N. Engl. J. Med. 2005, 352, 786-792. [CrossRef] [PubMed] 
7. Pao, W.; Miller, V.A.; Politi, K.A.; Riely, G.J.; Somwar, R.; Zakowski, M.F.; Kris, M.G.; Varmus, H. Acquired resistance of lung adenocarcinomas to gefitinib or erlotinib is associated with a second mutation in the EGFR kinase domain. PLoS Med. 2005, 2, e73. [CrossRef] [PubMed]

8. Kwak, E.L.; Sordella, R.; Bell, D.W.; Godin-Heymann, N.; Okimoto, R.A.; Brannigan, B.W.; Harris, P.L.; Driscoll, D.R.; Fidias, P.; Lynch, T.J.; et al. Irreversible inhibitors of the EGF receptor may circumvent acquired resistance to gefitinib. Proc. Natl. Acad. Sci. USA 2005, 102, 7665-7670. [CrossRef] [PubMed]

9. Bridjes, A.J. Chemical inhibitors of protein kinases. Chem. Rev. 2001, 101, 2541-2572. [CrossRef]

10. Sos, M.L.; Rode, H.B.; Heynck, S.; Peifer, M.; Fischer, F.; Klüter, S.; Pawar, V.G.; Reuter, C.; Heuckmann, J.M.; Weiss, J.; et al. Chemogenomic profiling provides insights into the limited activity of irreversible EGFR Inhibitors in tumor cells expressing the T790M EGFR resistance mutation. Cancer Res. 2010, 70, 868-874. [CrossRef] [PubMed]

11. Kim, Y.; Ko, J.; Cui, Z.; Abolhoda, A.; Ahn, J.S.; Ou, S.H.; Ahn, M.J.; Park, K. The EGFR T790M mutation in acquired resistance to an irreversible second-generation EGFR inhibitor. Mol. Cancer Ther. 2012, 11, 784-791. [CrossRef] [PubMed]

12. Zhou, W.; Ercan, D.; Chen, L.; Yun, C.H.; Li, D.; Capelletti, M.; Cortot, A.B.; Chirieac, L.; Iacob, R.E.; Padera, R.; et al. Novel mutant-selective EGFR kinase inhibitors against EGFR T790M. Nature 2009, 462, 1070-1074. [CrossRef] [PubMed]

13. Walter, A.O.; Sjin, R.T.; Haringsma, H.J.; Ohashi, K.; Sun, J.; Lee, K.; Dubrovskiy, A.; Labenski, M.; Zhu, Z.; Wag, Z.; et al. Discovery of a mutant-selective covalent inhibitor of EGFR that overcomes T790M-mediated resistance in NSCLC. Cancer Discov. 2013, 3, 1404-1415. [CrossRef] [PubMed]

14. Cross, D.A.; Ashton, S.E.; Ghiorghiu, S.; Eberlein, C.; Nebhan, C.A.; Spitzler, P.J.; Orme, J.P.; Finlay, M.R.; Ward, R.A.; Mellor, M.J.; et al. AZD9291, an irreversible EGFR TKI, overcomes T790M-mediated resistance to EGFR inhibitors in lung cancer. Cancer Discov. 2014, 4, 1046-1061. [CrossRef] [PubMed]

15. Finlay, M.R.; Anderton, M.; Ashton, S.; Ballard, P.; Bethel, P.A.; Box, M.R.; Bradbury, R.H.; Brown, S.J.; Butterworth, S.; Campbell, A.; et al. Discovery of a potent and selective EGFR inhibitor (AZD9291) of both sensitizing and T790M resistance mutations that spares the wild type form of the receptor. J. Med. Chem. 2014, 57, 8249-8267. [CrossRef] [PubMed]

16. Yver, A. Osimertinib (AZD9291) - A science-driven, collaborative approach to rapid drug design and development. Ann. Oncol. 2016, 27, 1165-1170. [CrossRef] [PubMed]

17. Yu, H.; Li, Y.; Ge, Y.; Song, Z.; Wang, C.; Huang, S.; Jin, Y.; Han, X.; Zhen, Y.; Liu, K.; et al. Novel 4-anilinoquinazoline derivatives featuring an 1-adamantyl moiety as potent EGFR inhibitors with enhanced activity against NSCLC cell lines. Eur. J. Med. Chem. 2016, 110, 195-203. [CrossRef] [PubMed]

18. Song, Z.; Jin, Y.; Ge, Y.; Wang, C.; Zhang, J.; Tang, Z.; Peng, J.; Liu, K.; Li, Y.; Ma, X. Synthesis and biological evaluation of azole-diphenylpyrimidine derivatives (AzDPPYs) as potent T790M mutant form of epidermal growth factor receptor inhibitors. Bioorg. Med. Chem. 2016, 24, 5505-5512. [CrossRef] [PubMed]

19. Song, Z.; Ge, Y.; Wang, C.; Huang, S.; Shu, X.; Liu, K.; Zhou, Y.; Ma, X. Challenges and Perspectives on the development of small-molecule EGFR inhibitors against T790M-mediated resistance in non-small-cell lung cancer. J. Med. Chem. 2016, 59, 6580-6594. [CrossRef] [PubMed]

20. The spectrum data for compound $\mathrm{N}$-(3-((5-chloro-2-(4-((1-morpholino)methyl)phenylamino)-4-pyrimidinyl) amino)phenyl)acrylamide (DY3002): Yield 56.6\%; off-white solid. ${ }^{1} \mathrm{H}$ NMR $\left(400 \mathrm{MHz}, \mathrm{DMSO}-d_{6}\right): \delta 3.32$ $(\mathrm{s}, 2 \mathrm{H}), 3.36(\mathrm{t}, J=7.6 \mathrm{~Hz}, 2 \mathrm{H}), 3.54-3.56(\mathrm{~m}, 6 \mathrm{H}), 5.76(\mathrm{dd}, J=2.0,10.4 \mathrm{~Hz}, 1 \mathrm{H}), 6.27(\mathrm{dd}, J=2.0,16.8 \mathrm{~Hz}, 1 \mathrm{H})$, $6.46(\mathrm{dd}, J=10.4,16.8 \mathrm{~Hz}, 1 \mathrm{H}), 7.03(\mathrm{~d}, J=8.4 \mathrm{~Hz}, 2 \mathrm{H}), 7.31(\mathrm{t}, J=6.0 \mathrm{~Hz}, 2 \mathrm{H}), 7.56(\mathrm{~m}, 3 \mathrm{H}), 7.91(\mathrm{~s}, 1 \mathrm{H}), 8.15$ $(\mathrm{s}, 1 \mathrm{H}), 8.96(\mathrm{~s}, 1 \mathrm{H}), 9.32(\mathrm{~s}, 1 \mathrm{H}), 10.20(\mathrm{~s}, 1 \mathrm{H}) .{ }^{13} \mathrm{C}-\mathrm{NMR}\left(400 \mathrm{MHz}, \mathrm{DMSO}-d_{6}\right): \delta 163.6,158.2,156.7,155.2$, $139.8,139.6,139.3,132.4,130.6,129.5(2 \mathrm{C}), 129.0,127.3,119.8,119.1$ (2C), 115.9, 115.8, 104.2, 66.7 (2C), 62.6, 53.6 (2C). HRMS (ESI) for $\mathrm{C}_{24} \mathrm{H}_{25} \mathrm{ClN}_{6} \mathrm{O}_{2},[\mathrm{M}+\mathrm{H}]^{+}$calcd: 465.1801 , found: 465.1808.

21. Huo, Y.; Qiu, W.; Pan, Q.; Yao, Y.; Xing, K.; Loua, M.F. Reactive oxygen species (ROS) are essential mediators in epidermal growth factor (EGF)-stimulated corneal epithelial cell proliferation, adhesion, migration, and wound healing. Exp. Eye Res. 2009, 89, 876-886. [CrossRef] [PubMed]

22. Wildman, S.A.; Zheng, X.; Sept, D.; Auletta, J.T.; Rosenberry, T.L.; Marshall, G.R. Drug-like leads for steric discrimination between substrate and inhibitors of human acetylcholinesterase. Chem. Biol. Drug Des. 2011, 78, 495-504. [CrossRef] [PubMed] 
23. Morris, G.M.; Huey, R.; Lindstrom, W.; Sanner, M.F.; Belew, R.K.; Goodsell, D.S.; Olson, A.J. AutoDock4 and AutoDockTools4: Automated docking with selective receptor flexibility. J. Comput. Chem. 2009, 30, 2785-2791. [CrossRef] [PubMed]

24. Soria, J.C.; Sequist, L.V.; Goldman, J.; Wakelee, H.A.; Neal, J.; Camidge, R.; Gadgeel, S.; Papadimitrakopoulou, V.; Dziadziuszko, R.; Piotrowska, Z.; et al. Rociletinib: An oral, irreversible, highly selective small molecule inhibitor of mutant EGFR including T790M. Ann. Oncol. 2015, 26, ii14. [CrossRef]

25. Sequist, L.V.; Soria, J.C.; Goldman, J.W.; Wakelee, H.A.; Gadgeel, S.M.; Varga, A.; Papadimitrakopoulou, V.; Solomon, B.J.; Oxnard, G.R.; Dziadziuszko, R.; et al. Rociletinib in EGFR-mutated non-small-cell lung cancer. N. Engl. J. Med. 2015, 372, 1700-1709. [CrossRef] [PubMed]

Sample Availability: Samples of the compounds DY3002 are available from the authors.

(C) 2016 by the authors; licensee MDPI, Basel, Switzerland. This article is an open access article distributed under the terms and conditions of the Creative Commons Attribution (CC-BY) license (http://creativecommons.org/licenses/by/4.0/). 